\title{
Bank Ownership and Efficiency in Post-conflict Era: Evidence from Sri Lanka
}

\author{
Bolanda Thilakaweera, Charles Harvie, and Amir Arjomandi \\ Faculty of Business, University of Wollongong, Australia
}

\author{
bhpkt989@uowmail.edu.au; charvie@uow.edu.au; \\ amira@uow.edu.au
}

\begin{abstract}
This paper aims to explore the changes in efficiency of state-owned, domestic private and foreign banks in Sri Lanka after the ending of the 26 year long armed-conflict between the government and ethnic Tamil rebels in 2009. (The Liberation Tigers for Tamil Eelam (LTTE) fought for a separate state called "Tamil Eelam" from 1983 to 2009. Government forces defeated the LTTE rebels in mid-2009 through military operations and capturing all the land belonging to their de facto state for more than a decade.) Data Envelopment Analysis (DEA) along with the bootstrap simulation technique is employed to derive bank-wise efficiency scores. Two approaches, namely the intermediation and operating approaches, are used to measure the efficiency of banks and to analyse banking performance from multiple perspectives. The results show that, under the intermediation approach, in general state-owned banks were less efficient than domestic private banks in 2009 and 2010, but the relative efficiency of state-owned banks improved in 2011 and 2012 surpassing both domestic private and foreign banks. In contrast our results reveal that under the profit-oriented operating approach, state-owned and foreign banks show superior average efficiency than domestic private banks. The findings reflect the strong positioning of state-owned banks, in line with the post-conflict economic expansion of Sri Lanka, in providing efficient banking services.
\end{abstract}

Keywords: Efficiency, Bank, Ownership, Intermediation Approach, Operating Approach.

\section{Introduction}

Similar to many other emerging economies the banking industry is the dominant player in the financial sector in Sri Lanka, which consists of banks with three different ownership types: stateowned banks, private domestic banks and foreign banks. The foreign banks existed even before achieving independence in 1948 and their operations were limited by successive governments in the post-independence period until 1977. Economic reforms introduced in 1977 improved diver-

Material published as part of this publication, either on-line or in print, is copyrighted by the Informing Science Institute. Permission to make digital or paper copy of part or all of these works for personal or classroom use is granted without fee provided that the copies are not made or distributed for profit or commercial advantage AND that copies 1) bear this notice in full and 2) give the full citation on the first page. It is permissible to abstract these works so long as credit is given. To copy in all other cases or to republish or to post on a server or to redistribute to lists requires specific permission and payment of a fee. Contact Publisher@InformingScience.org to request redistribution permission. sification in the ownership structure of the banking industry by encouraging private and foreign banks to expand their services in Sri Lanka. Currently, two state-owned commercial banks are the market leaders accounting for $44 \%$ of commercial banking assets while private and foreign banks account for the remaining 56\%. The Central Bank of Sri Lanka (CBSL) is responsible for regu- 
lating the banking industry in Sri Lanka while implementing appropriate credit and monetary policy in line with developments in the economy.

All these state-owned, private and foreign banks expanded their operations aggressively in terms of branch networks, assets, liabilities, lending and deposits after the ending of a quarter century long bloody civil-war in Sri Lanka in 2009. An expansion in economic activities with improvements in investor sentiments due to the establishment of long-lasting peace in the country 1 , getting access to agricultural land in rebel held areas and revival of livelihood activities in war affected areas provided the necessary ingredient for banking institutions to expand their services. Although the literature on banking efficiency shows how ownership structures of banks links with efficiency of the banking industry (Altunbas et al., 2001; Berger, 2007; Burki \& Niazi, 2010; Das \& Gosh, 2006; Demir et al., 2005; Fries \& Taci, 2005; Ray \& Das, 2010), too little attention has been paid to evaluating this relationship when the economy experiences a favourable economic shock such as post-conflict economic developments. Therefore the present study evaluates how the ownership type of banks matter in terms of efficiency when the economy moves into a higher growth path in a post-conflict era.

This study employed Data Envelopment Analysis (DEA) to calculate the technical efficiency of the 15 main commercial banks in Sri Lanka, which together account for $96 \%$ of total assets held by commercial banks in the country. DEA is the most commonly accepted and widely used technique in banking sector efficiency analysis, mainly due to two reasons (Andries 2011; Burki \& Niazi, 2010; Casu \& Molyneux, 2003; Grabowski et al., 1993; Kenjegalieva et al., 2009; Sharmen $\&$ Gold, 1985). First, DEA does not require a functional form for the production process of the firm (bank) and it is challenging to identify a correct production function when producing intangible services such as that produced by banks. Therefore, the efficiency estimates derived from DEA are not prone to errors from the functional form as in the case of parametric methods. Second, the functional forms used in parametric methods are only true in large samples and studies on banking efficiency are mostly handicapped by small sample sizes. However efficiency scores calculated based on small samples using the standard DEA has been criticised in the recent literature, highlighting the biasedness in DEA estimators due to the non-measurement of random errors and the existence of sampling errors (Keramidou \& Mimis, 2011; Simar \& Wilson, 1998, 2000). This study, therefore, uses the bootstrapping techniques introduced in Simar and Wilson (1998, $2000,2007)$ to avoid these shortcomings in standard DEA efficiency scores.

\section{Literature Review}

Sharmen and Gold (1985) were the first to investigate banking efficiency using the frontier method. With the development of new methodologies in measuring firm efficiency there was an unprecedented growth in articles pertaining to the analysis of efficiency in the banking sector. Initially, academics and policy makers mainly focused on the US and European banking sectors due to the availability of quality data (Berger \& Humphrey, 1991; Berger et al., 1993; De Guevara \& Maudos, 2002). Although studies of banking efficiency were less prevalent in the past, more recent studies have evaluated banking efficiency subsequent to significant financial reforms in most countries (Arjomandi et al., 2012; Barros et al., 2011; Das \& Ghosh, 2006; Drake et al., 2006; Hasan \& Marton, 2003; Sahoo \& Tone, 2009; Seelanatha, 2012; Sufian, 2009). With these reforms the banking sector in those countries experienced changes in ownership structure involving greater private sector participation. Reforms encouraged both domestic private and foreign partic-

\footnotetext{
${ }^{1}$ With the recent peaceful domestic environment achieved through military operations, Sri Lanka recorded unprecendeted real GDP growth of over 8\% in both 2010 and 2011. Despite fragile economic conditions in the advanced countries in 2012, Sri Lanka achieved a $6.4 \%$ economic growth rate with continued expansion in economic activities
} 
ipation by allowing them to compete freely with state-owned banks. The diversified market structure following these reforms provided the necessary ingredient for economists to evaluate the efficiency levels of banking institutions based upon type of ownership.

The majority of the empirical literature has focused on changes in the efficiency level of banks based on ownership type and have highlighted that domestic private and foreign owned banks outperform state-owned banks (Altunbas et al., 2001; Berger, 2007; Burki \& Niazi, 2010; Demir et al., 2005; Fries \& Taci, 2005). However Gerschenkron (1962) justified government ownership in strategic economic sectors such as banking, emphasising the necessity of financial services for economic growth in the absence of private participation. In more recent literature, La Porta et al. (2002) also argued that government ownership in banking allows more control over resource allocation and in the implementation of projects as opposed to regulating banks to try and ensure optimum allocation of funds. He also identified government intervention in financing firms as a strategy to overcome institutional failures and enhance aggregate demand for fostering economic growth. However, the findings of La Porta et al. (2002) based on 92 countries revealed a negative relationship between government ownership of banks and economic growth and financial sector development. In contrast, a number of empirical studies in banking efficiency focusing on some countries found higher efficiency for state-owned banks relative to private banks (Das \& Gosh, 2006, Ray \& Das, 2010).

In addition to the comparison of efficiency between state-owned banks and private banks, a number of studies have identified significant differences in efficiency between domestic banks and foreign banks arising from increasing cross-border expansion in foreign banking operations stimulated by financial sector reforms throughout the world (Berger, 2007; Hasan \& Marton, 2003; Havrylchyk, 2006; Lensink et al., 2008; Mamatzakis et al., 2008). Technological advancement, particularly in information technology, makes it easier to monitor branch performances across nations, and ever increasing financial flows across international borders with international trade has also stimulated an expansion in banks operating across territorial borders. Berger (2007) argued that the negative impact of cross broader expansions or distance could be overcome through efficiency gains, as parent banks can use their superior skills, policies and practices to improve the efficiency of branches away from headquarters. However this argument is mostly true for the developed countries as foreign banks generally do not outperform their domestic counterparts in developing countries (Berger 2007; Berger \& De Young, 2001). The literature explains the lower efficiency of foreign banks in developing countries as an outcome of the poor regulatory environment which limits the performance of foreign banks. As against this view, some empirical findings support the conclusion that foreign banks are more efficient in developing countries relative to domestic banks arising from exploitation of their comparative advantages. (Bhattacharyya et al., 1997; Grigorian \& Manole, 2002; Hasan \& Marton, 2003; Isik \& Hassan, 2002; Zajc 2006).

Although the separation of ownership from control is a common issue in all types of ownership categories of the banking sector, agency theory has also been used to explain the differences in performance levels among different types of ownership categories. Altubas et al. (2001) argued that inadequate financial market disciplines in state-owned banks due to low intensity of shareholder pressure could reduce the efficiency levels of those banks relative to private banks. Low efficiency levels are highlighted as an outcome of management decisions based on their personal agenda or political influences in the absence of financial market discipline. Improvement in corporate governance practices is proposed by many studies to alleviate the agency problem by introducing better controls and effective monitoring of management (Barth et al., 2006; Becht et al., 2002; Bokpin, 2013; Johnson et al., 2000; Shleifer \& Vishny, 1997). 


\section{Banking Sector in Sri Lanka}

The history of the Sri Lankan formal financial sector begins with the establishment of foreign banks in the late $19^{\text {th }}$ century by the British rulers who occupied the entire Island in 1815 . At the regaining of independence in 1948 Sri Lanka had a financial sector which catered primarily to the plantation industry ${ }^{2}$ and commercial trading activities only took place in urban areas (CBSL, 1998). The financial sector was dominated by foreign commercial banks while a few finance companies and savings institutions were in operation based in the capital city Colombo. Financial sector development in the post-independence era started with the establishment of the Central Bank of Sri Lanka (CBSL) in 1950, the apex body of the financial system of Sri Lanka, replacing a currency board system. There was a gradual increase in banking penetration with state intervention in the banking industry establishing government commercial and savings banks.

The expansion in services provided by private and foreign-owned financial institutions was further encouraged by economic reforms introduced in $1977^{3}$ with the aim of liberalising the economy (CBSL, 1998). However, the ethnic conflict that erupted between LTTE rebels and government forces in 1983 decelerated expansion in the banking sector due to the deterioration of the overall economic environment, and the sector maintained moderate growth despite ongoing reforms. The CBSL was empowered with more regulations and controls over the banking sector in Sri Lanka by the Banking Act 1988. Directions were issued by the CBSL, with amendments to the Banking act, for new broad disclosure requirements of financial data of the banking sector, single borrower limits, statutory reserve requirements (SRR), a risk-weighted capital-adequacy ratio (CAR), ownership structure, corporate governance and other banking operation measures to ensure the smooth and efficient functioning of the banking sector ${ }^{4}$. With the gradual changes in structure of the ownership of the banking sector, total banking assets owned by the private banks surpassed the banking assets owned by government banks in 2002 (Hemachandra, 2009). The ending of the armed-conflict in 2009 significantly improved the business climate in Sri Lanka, adding momentum to expansion of the banking industry in terms of service volumes and branch networks. State-owned, domestic private and foreign banks expanded their branch network throughout the country. A number of banks expanded their operation in two conflict-affected regions to take advantage of pent-up demand for banking services with resettlements, reconstruction and the revival of economic activities.

As depicted in Table 1 the banking sector is the dominant player in the financial sector in Sri Lanka, controlling most of the financial flows and possessing most of the financial assets. There are 24 licensed commercial banks (LCB), 9 licenced specialized banks (LSB) and 47 registered finance companies operating in the country ${ }^{5}$ (CBSL 2012). The total number of commercial bank

\footnotetext{
${ }^{2}$ Tea, rubber and coconut are the main plantation crops in Sri Lanka which accounted for $18 \%$ of annual export revenue in 2012 (CBSL 2012).

${ }^{3}$ In 1977 the country adopted open market economic liberalisation policies aimed at minimising government intervention in the economy. During the period 1956 - 1976 the intensity of government intervention in the economy was very high with closed economic policies and import substitution as the main theme of the government's development policy agenda.

${ }^{4}$ Reforms introduced by the Central Bank of Sri Lanka mostly focused on improving the soundness, stability and governance of the banking sector while providing equal opportunities for private banks to establish in the market.

${ }^{5}$ These 24 commercial banks are allowed to do any banking activity in Sri Lanka. Nine LSBs are mostly focused on savings and development banking rather than commercial banking activities. These LSBs are not allowed to accept demand deposits which are not entitled to an interest payment from the banks.
} 
branches increased gradually from 2009 to 2012 with expansion of the banking sector. It is a well-known fact that high banking institution efficiency stimulates the economy by minimising the cost of funds and improving investments. Therefore, efficiency of the banking sector is important for economic growth as well as the sustainability of banking institutions in the long run. However an optimum level of economic growth could not be expected through expansion in the banking sector in terms of branch networks and service volumes alone if significant disparities in banking efficiency prevail among the banks. Therefore the comparative analysis of efficiency among different ownership categories of banks from 2009 to 2012 provided by this study is essential in order to formulate necessary policies in the banking sector aimed at attaining higher efficiency.

Table 1: Structure of the assets and deposit liabilities of the main institutions in the formal financial sector in Sri Lanka as of 30.09.2012

\begin{tabular}{|l|r|r|}
\hline Institutions & Assets (\%) & \multicolumn{1}{|c|}{ Deposits (\%) } \\
\hline Central Bank of Sri Lanka & 15.4 & n.a \\
\hline Financial Institutions Regulated by the Central Bank & & \\
\hline Deposit Taking Institutions & & \\
\hline Licensed Commercial Banks & 47.8 & 77.5 \\
\hline Licensed Specialized Banks & 8 & 14.3 \\
\hline$\quad$ Licensed Finance Companies & 4.9 & 6.2 \\
\hline Other Financial Institutions & & \\
\hline$\quad$ Primary Dealers & 1.5 & n.a. \\
\hline$\quad$ Specialized Leasing companies & 1.5 & n.a. \\
\hline Institutions not Regulated by the Central Bank $\left({ }^{\mathrm{a}}\right)$ & 20.9 & 2 \\
\hline All $\quad 100$ & 100 \\
\hline
\end{tabular}

Source: Central Bank of Sri Lanka

(a) Institutions not regulated by the Central Bank of Sri Lanka include Rural Banks, Thrift and Credit Co-operative Societies, Employees' Provident Funds, Insurance Companies, Stock Broking Companies, Unit Trusts/ Unit Trust Management Companies, Market Intermediaries such as Underwriters, Margin Providers, Investment Managers, Credit Rating Agencies and Venture Capital Companies.

n.a - not applicable

\section{Methodology}

After the introduction of DEA by Charnes et al. (1978) and Banker et al. (1984) for the purpose of calculating efficiency, banking sector efficiency studies have widely adopted this method to compile their efficiency scores (Andries, 2011; Burki \& Niazi, 2010; Casu \& Molyneux, 2003; Grabowski et al., 1993; Kenjegalieva et al., 2009; Sharmen \& Gold, 1985). Liu et al. (2013) showed that the largest application of DEA techniques are reported in the field of banking, based on all research papers published in journals indexed by the Web of Science database from 1978 to 2010 .

In DEA a linear programing technique is employed in estimating efficient production frontiers (Berger \& Humphrey, 1997) and a pre-specified functional form of the production process is not imposed on the data to derive a production frontier (Kalirajan \& Shand, 1994). This nonparametric piece-wise frontier is estimated using the given sample of data. After estimating the frontier efficiency scores are calculated relative to the frontier. The firms that lie on the frontier score a value "1" as fully efficient institutions which are enveloped by an efficient frontier. The 
banks lying below the frontier score values of between " 0 " and " 1 " and are relatively inefficient institutions.

Although DEA as first introduced by Charnes et al. (1978) is based on the assumption of Constant Return to Scale (CRS), this is only valid when firms are operating at optimal scale. However, firms are not operating at optimum scale most of the time due to imperfect competition, regulations, and limitations which are particularly pertinent for the case of financial sector institutions such as banks. Therefore DEA under Variable Returns to Scale (VRS) introduced by Afriat (1972), Fare et al. (1983) and Banker et al. (1984) have been used for this study with an outputorientation, which measures the efficiency of the firms by considering maximum output expected from given inputs.

Using the duality characteristics in linear programing, efficiency scores can be derived by solving an envelope form of the following output-oriented linear programming problem.

$$
\begin{gathered}
\max _{\theta, \lambda} \quad \theta \\
\text { st. } \quad-\theta q_{i}+Q \lambda \geq 0, \\
x_{i}-X \lambda \geq 0, \\
I 1^{\prime} \lambda=1 \\
\lambda \geq 0
\end{gathered}
$$

There are $N$ inputs and $M$ outputs for the total number of firms I. $X$ is an $N \times I$ matrix and Q is an $M \times I$ matrix. Where $\theta$ is a scalar and $\lambda$ is a $I \times 1$ matrix of constants. Inputs and output are represented by $x_{i}$ and $q_{i}$ respectively. The efficiency of the $i^{\text {th }}$ firm is given by $1 / \theta$ while $\theta-1$ is the proportional increase in outputs when the input level is held constant.

Efficiency scores based on DEA, however, have been criticised in more recent literature due to possible biasedness, due to the non-measurement of random errors and the existence of sampling errors (Keramidou \& Mimis, 2011; Simar \& Wilson, 1998, 2000). Therefore, bootstrapping techniques introduced by Simar and Wilson $(1998,2000,2007)$ are used in this study to avoid these shortcomings in the standard DEA efficiency scores. Bootstrap techniques employ a large number of pseudo samples drawn from the given data to estimate the efficiency scores and confidence intervals of the same. The large number of pseudo samples is used by the bootstrapping technique to form an approximation for the true distribution asymptotically. Simar and Wilson $(1998,2000$, 2007) have provided bootstrap algorithms to calculate bias-corrected DEA estimates.

\section{Data, Inputs and Outputs Specifications}

Unlike for the case of a manufacturing firm the selection of relevant inputs and output for a banking institution is a challenge, due to greater complexity in the production of banking services.

Most banking services are jointly produced while prices are assigned to a bundle of services such as providing credit to firms with the necessary guidance for liquidity management and project evaluation. Different approaches have been used in the literature for a clearer identification of inputs and output to be used in measuring banking efficiency. The intermediation approach is mostly used for the case of banking efficiency. In comparison to the intermediation approach, there are far fewer banking efficiency studies based on the operating, value added and revenue approaches (Altunbas et al., 2001; Bos \& Kolari, 2005; Casu \& Girardone, 2009; Isshaq \& Bokpin, 2012; Maudos et al., 2002; Ray \& Das, 2010). The intermediation approach is based on the production process of services by banks, although the production of services, particularly with respect to banks, is complex. The other three approaches are based on the operations, valueadditions and revenue generation of the banking system (Suffian, 2011). Since private banks are highly concerned about profit and revenue maximisation the literature on banking efficiency suggests the operating approach particularly in a comparison of state-owned banks and private banks 
rather than the intermediation approach, which does not measure efficiency incorporating revenue (Berger \& Mester, 2003, Arjomandi et al., 2014). Accordingly, this study compiles efficiency scores based on the Intermediation and Operating approaches to analyse banking performance from multiple perspectives. The total number of permanent employees $\left(x_{1}\right)$, fixed assets $\left(x_{2}\right)$ and total deposits $\left(x_{3}\right)$ collected are the inputs for the intermediation approach, while total advances $\left(y_{1}\right)$ are taken as the output. The operating approach employs total interest expenses $\left(x_{4}\right)$ and non-interest expenses $\left(x_{5}\right)$ as inputs and total interest income $\left(y_{2}\right)$ and non-interest income $\left(y_{3}\right)$ as outputs. The data used in this study was extracted from the annual reports of the respective banks and publications of the Central Bank of Sri Lanka. The sample consists of 2 state-owned banks, 7 private banks and 6 foreign banks for the period 2009 - 2012. Table 2 shows the distribution of banking assets among the selected 15 banks.

Table 2: Distribution of the assets of the commercial banks in Sri Lanka

\begin{tabular}{|l|l|r|r|}
\hline Name of the bank & Ownership Category & $\begin{array}{c}\text { Total Assets in } \\
\text { US\$ million as } \\
\text { at end 2012 }\end{array}$ & $\begin{array}{c}\text { Market share of } \\
\text { Commercial } \\
\text { Banking Assets } \\
\text { at end 2012 (\%) }\end{array}$ \\
\hline 1. Bank of Ceylon & State-owned & $8,214.9$ & 24.0 \\
2. People's Bank & State-owned & $6,844.0$ & 20.0 \\
3. Commercial Bank & Private-Domestic & $4,010.5$ & 11.7 \\
4. Hatton National Bank & Private-Domestic & $3,498.1$ & 10.2 \\
5. Sampath Bank & Private-Domestic & $2,424.8$ & 7.1 \\
6. HSBC & Foreign & $2,219.3$ & 6.5 \\
7. Seylan Bank & Private-Domestic & $1,439.4$ & 4.2 \\
8. National Development Bank $\left({ }^{b}\right)$ & Private-Domestic & $1,281.1$ & 3.8 \\
9. Nations Trust Bank & Private-Domestic & 951.0 & 2.8 \\
10. Standard Chartered Bank & Foreign & 827.0 & 2.4 \\
11. Pan Asia Banking Corporation & Private-Domestic & 439.5 & 1.3 \\
12. Indian Bank & Foreign & 241.0 & 0.7 \\
13. Citibank, N.A. & Foreign & 202.1 & 0.6 \\
14. Indian Overseas Bank & Foreign & 151.8 & 0.4 \\
15. State Bank of India & Foreign & 151.5 & 0.4 \\
\multicolumn{1}{|c|}{ Other Banks } & 3 domestic private \& 6 & & 3.7 \\
\hline All Commercial Banks & & 1267.3 & 100.0 \\
\hline Soureign banks( $\left.{ }^{(}\right)$ & - & $34,163.2$ & \\
\hline
\end{tabular}

Source: Annual reports of the respective commercial banks and publications of the Central Bank of Sri Lanka.

(a) Three domestic private banks: DFCC Vhardana Bank; Amana Bank;Union Bank and six foreign banks: Deutsche Bank AG.;ICICI Bank; MCB Bank; Public Bank Berhad; Habib Bank; Axis Bank.

(b) The National Development Bank is a joint stock bank owned by the Sri Lankan government and the private sector. The bank is categorised as private bank based on banking practices.

\section{Empirical Results}

The efficiency scores for each bank in each year were calculated based on a pooled frontier for the period 2009-2012. As explained in the methodology section the efficiency of a bank should be between " 1 " and " 0 ". Fully efficient banks score " 1 " and lie on the frontier while relatively inefficient banks are always off the frontier. According to Table 3 the decline in the standard deviation of the efficiency scores under the intermediation approach over time shows the convergence 
of efficiency in the banking sector during the period 2009-2012. This shows that the inequality in efficiency levels of intermediation services among the banking institutions declined during the reference period. However, the results do not provide clear evidence for the convergence of operational efficiency based on efficiency scores calculated under the operating approach.

Table 3: Average annual efficiency scores for the banking sector based on bootstrap DEA (2009 - 2012)

\begin{tabular}{|c|c|c|c|c|}
\hline \multirow{2}{*}{ Year } & \multicolumn{2}{|c|}{ Intermediation Approach } & \multicolumn{2}{c|}{ Operating Approach } \\
\cline { 2 - 4 } & Efficiency Scores & \multirow{2}{*}{ Std. Deviation } & Efficiency Scores & \multirow{2}{*}{ Std. Deviation } \\
\cline { 2 - 4 } & (Bias-Corrected) & & 0.7926 & 0.0824 \\
\hline 2009 & 0.6478 & 0.1245 & 0.8067 & 0.0587 \\
\hline 2010 & 0.6805 & 0.1119 & 0.7760 & 0.0886 \\
\hline 2011 & 0.7386 & 0.0764 & 0.8089 & 0.0737 \\
\hline 2012 & 0.7471 & 0.0921 & & \\
\hline
\end{tabular}

Table 4: Average bias corrected efficiency of commercial banks in Sri Lanka by type of ownership

\begin{tabular}{|l|c|c|c|}
\hline \multirow{2}{*}{ Ownership Category } & \multirow{2}{*}{ Year } & \multicolumn{2}{|c|}{ Approach } \\
\cline { 3 - 4 } & & Intermediation & Operating \\
\hline Sate-owned Banks & 2009 & 0.6244 & 0.7579 \\
\hline & 2010 & 0.7312 & 0.8690 \\
\hline & 2011 & 0.7966 & 0.8384 \\
\hline & 2012 & 0.8026 & 0.8103 \\
\hline & & & \\
\hline Private Commercial Banks & 2009 & 0.6440 & 0.7297 \\
\hline & 2010 & 0.7400 & 0.7552 \\
\hline & 2011 & 0.7582 & 0.7483 \\
\hline & 2012 & 0.7308 & 0.7760 \\
\hline Foreign Banks & & & \\
\hline & 2009 & 0.6599 & 0.8777 \\
\hline & 2010 & 0.5943 & 0.8459 \\
\hline & 2011 & 0.6965 & 0.7876 \\
\hline & 2012 & 0.7476 & 0.8468 \\
\hline
\end{tabular}

Table 4 provides a summary of the average efficiency levels of aggregate groupings of individual banks during the period $2009-2012$, based on both the intermediation and operating approaches. The results reveal that under the intermediation approach the average efficiency of domestic private banks during 2009 and 2010 is higher than that of the state-owned banks. However, stateowned banks were able to record a relatively higher level of average efficiency compared to that of private domestic banks in 2011 and 2012. Although the average efficiency of foreign banks is relatively higher in 2009 the other ownership categories outperformed the foreign banks in 2010 and 2011. Further, the results reveal that, in general, the average efficiency of foreign banks improved during the reference period, presumably because some of the foreign banks down sized their staff after 2009. An upward trend can also be seen in the average efficiency of private and 
state-owned banks during this period. This is in line with the pattern of expansion of banking sector credit after the ending of armed-conflict in 2009. With expansion in the economy due to high domestic demand followed by reconstruction and resettlement in conflict affected areas, banking sector credit expanded by $0.5 \%, 18 \%$ and $34 \%$ in 2009, 2010 and 2011 respectively (CBSL 2010; $2011 ; 2012)^{6}$. Credit growth decelerated to $21 \%$ with the imposition of restrictions on credit growth in 2012 by the Central Bank of Sri Lanka as a measure of stabilising the economy due to a deterioration of the balance of payments. During the year 2010, 2011 and 2012 state-owned banks and domestic private banks which expanded their branch network aggressively and introduced new loan schemes to conflict affected areas, recorded higher average efficiency than foreign banks in providing intermediation services. In general, higher efficiency in intermediation services could not be expected from the foreign banks operating in Sri Lanka with the post-conflict economic expansion, since most of these banks earned a considerable percentage of their income providing some other services to their customers other than lending.

Although the literature on banking efficiency supports the view of higher efficiency in private banks, domestic private banks in Sri Lanka recorded relatively lower average efficiency than state-owned banks and foreign banks based on the profit-oriented operating approach. This is likely because domestic private banks have to compete for deposit mobilization particularly with the government banks, which are able to attract deposits at relatively lower cost (interest) due to the implicit government guarantee. On the other hand some of the foreign banks can use the trust in them to attract deposits due to their global presence and scale. Unlike the intermediation approach an upward trend in average efficiency levels of each ownership category cannot be found in the results based on the operating approach. One possible explanation for less improvement in efficiency based on the profit-oriented operating approach is more focus of banking institution on intermediation services through branch expansion of those banks to exploit advantages of pent-up demand for credit particularly in the Northern and Eastern regions of the country.

Tables 5 and 6 list efficiency and efficiency related measures for each bank to provide a comprehensive picture of changes in efficiency levels from 2009 to 2012. Tables 5 and 6 include efficiency scores based on standard DEA (Std. efficiency), bias corrected efficiency scores (BC efficiency), rank of the efficiency level of the bank (Rank), changes in the rank from 2009 to 2012 (Rank Change) and the difference in bias corrected efficiency scores between 2009 and 2012 (Difference in BC-efficiency). According to the efficiency measures and ranks, state-owned banks were able to improve their relative efficiency of providing intermediation services as against the other two ownership categories. However, a majority of domestic private banks and foreign banks recorded a decline or no improvement in rank of their relative efficiency from 2009 to 2012. Improvement in relative efficiency of intermediation could be expected in state-owned banks since they were extensively involved in disbursing loans particularly to conflict affected areas with their branch expansion during this period. Under the operating approach, as shown in Table 6, the efficiency level of the two state-owned banks improved while the rank of the efficiency level of the Peoples bank declined by two positions. In general, based on the efficiency scores and the rank, the operational efficiency of private domestic banks improved while foreign banks stagnated.

\footnotetext{
${ }^{6}$ In early 2012 the Central Bank of Sri Lanka (CBSL) took some actions to avoid a balance of payments crisis such as tight monetary policy, imposing a credit ceiling on all commercial and savings banks under Section 101(1) of the Monetary Law Act and minimising the CBSL influence on the exchange rate. Simultaneously the government of Sri Lanka also imposed heavy taxes on selected imports, particularly motor vehicles, in order to dampen the demand for foreign currency.
} 
Table 5: Efficiency of the individual banks in 2009 and 2012 based on intermediation approach

\begin{tabular}{|c|c|c|c|c|c|c|c|c|}
\hline \multirow[b]{2}{*}{ Banking Institution } & \multirow[b]{2}{*}{$\begin{array}{c}\text { Std. } \\
\text { Efficiency }\end{array}$} & \multicolumn{2}{|c|}{2009} & \multicolumn{3}{|c|}{2012} & \multirow[b]{2}{*}{$\begin{array}{c}\text { Rank } \\
\text { Change }\end{array}$} & \multirow{2}{*}{$\begin{array}{c}\text { Difference } \\
\text { in } \\
\text { BC- } \\
\text { Efficiency } \\
(2009- \\
2012)\end{array}$} \\
\hline & & $\begin{array}{c}\text { BC } \\
\text { Efficiency }\end{array}$ & Rank & $\begin{array}{c}\text { Std. } \\
\text { Efficiency }\end{array}$ & $\begin{array}{c}\text { BC } \\
\text { Efficiency }\end{array}$ & Rank & & \\
\hline \multicolumn{9}{|l|}{ State-owned Banks } \\
\hline Bank of Ceylon & 0.6665 & 0.6120 & 11 & 1.0000 & 0.7958 & 7 & 4 & 0.1838 \\
\hline People's Bank & 0.6756 & 0.6369 & 10 & 1.0000 & 0.8094 & 5 & 5 & 0.1725 \\
\hline \multicolumn{9}{|l|}{ Domestic Private Banks } \\
\hline Commercial Bank & 0.7316 & 0.6887 & 6 & 0.8503 & 0.7480 & 9 & -3 & 0.0593 \\
\hline Hatton National Bank & 0.7490 & 0.7280 & 3 & 0.8580 & 0.8063 & 6 & -3 & 0.0783 \\
\hline National Development Bank & 0.8444 & 0.7717 & 2 & 1.0000 & 0.8363 & 2 & 0 & 0.0645 \\
\hline Nations Trust Bank & 0.6041 & 0.5798 & 13 & 0.6740 & 0.6278 & 13 & 0 & 0.0480 \\
\hline Pan Asia Bank & 0.4127 & 0.3812 & 15 & 0.6624 & 0.6295 & 14 & 1 & 0.2483 \\
\hline Sampath Bank & 0.6784 & 0.6506 & 9 & 0.8057 & 0.7535 & 8 & 1 & 0.1029 \\
\hline Seylan Bank & 0.7360 & 0.7078 & 4 & 0.7544 & 0.7141 & 11 & -7 & 0.0062 \\
\hline \multicolumn{9}{|l|}{ Foreign Banks } \\
\hline Indian Bank & 1.0000 & 0.6845 & 7 & 1.0000 & 0.8230 & 3 & 4 & 0.1385 \\
\hline Indian Overseas Bank & 1.0000 & 0.6758 & 8 & 1.0000 & 0.7009 & 12 & -4 & 0.0250 \\
\hline Citibank, N.A. & 0.4570 & 0.4145 & 14 & 0.5671 & 0.5228 & 15 & -1 & 0.1082 \\
\hline Standard Chartered Bank & 1.0000 & 0.9036 & 1 & 0.8965 & 0.8168 & 4 & -3 & -0.0868 \\
\hline State Bank of India & 1.0000 & 0.6959 & 5 & 0.8506 & 0.7431 & 10 & -5 & 0.0472 \\
\hline HSBC & 0.6503 & 0.5852 & 12 & 0.9682 & 0.8788 & 1 & 11 & 0.2936 \\
\hline
\end{tabular}

Correlation coefficient between efficiency in 2009 and difference in efficiency during the period $=-0.61$

Further a negative correlation existed between the efficiency levels of selected commercial banks in 2009 and improvement in efficiency during the reference period (third column and the last column of Tables 5 and 6). This suggests a higher efficiency improvement in relatively inefficient banks during the reference period. Therefore, less efficient banks in 2009 may manage to catchup with efficient banks in the future. 
Table 6: Efficiency of the individual banks in 2009 and 2012 based on operating approach

\begin{tabular}{|c|c|c|c|c|c|c|c|c|}
\hline \multirow[b]{2}{*}{ Banking Institution } & \multicolumn{3}{|c|}{2009} & \multicolumn{3}{|c|}{2012} & \multirow[b]{2}{*}{$\begin{array}{c}\text { Rank } \\
\text { Change }\end{array}$} & \multirow{2}{*}{\begin{tabular}{|c} 
Difference \\
in \\
BC- \\
Efficiency \\
$(2009-$ \\
$2012)$ \\
\end{tabular}} \\
\hline & $\begin{array}{c}\text { Std. } \\
\text { Efficiency }\end{array}$ & $\begin{array}{c}\text { BC } \\
\text { Efficiency }\end{array}$ & Rank & $\begin{array}{c}\text { Std. } \\
\text { Efficiency }\end{array}$ & $\begin{array}{c}\text { BC } \\
\text { Efficiency }\end{array}$ & Rank & & \\
\hline \multicolumn{9}{|l|}{ State-owned Banks } \\
\hline Bank of Ceylon & 0.8131 & 0.7424 & 10 & 1.0000 & 0.8220 & 6 & 4 & 0.0795 \\
\hline People's Bank & 0.8114 & 0.7734 & 8 & 0.8785 & 0.7986 & 10 & -2 & 0.0252 \\
\hline \multicolumn{9}{|l|}{ Domestic Private Banks } \\
\hline Commercial Bank & 0.7446 & 0.6976 & 13 & 1.0000 & 0.9118 & 2 & 11 & 0.2142 \\
\hline Hatton National Bank & 0.7582 & 0.7301 & 11 & 0.8556 & 0.8181 & 7 & 4 & 0.0880 \\
\hline National Development Bank & 0.9057 & 0.8501 & 6 & 0.8123 & 0.7548 & 11 & -5 & -0.0953 \\
\hline Nations Trust Bank & 0.7180 & 0.6812 & 15 & 0.7194 & 0.6940 & 15 & 0 & 0.0129 \\
\hline Pan Asia Bank & 0.7109 & 0.6856 & 14 & 1.0000 & 0.8163 & 9 & 5 & 0.1307 \\
\hline Sampath Bank & 0.8079 & 0.7651 & 9 & 0.7440 & 0.6944 & 14 & -5 & -0.0706 \\
\hline Seylan Bank & 0.7320 & 0.6979 & 12 & 0.7626 & 0.7424 & 12 & 0 & 0.0445 \\
\hline \multicolumn{9}{|l|}{ Foreign Banks } \\
\hline Indian Bank & 0.9462 & 0.8797 & 4 & 1.0000 & 0.8807 & 4 & 0 & 0.0010 \\
\hline Indian Overseas Bank & 1.0000 & 0.8176 & 7 & 0.7596 & 0.7119 & 13 & -6 & -0.1057 \\
\hline Citibank, N.A. & 1.0000 & 0.8626 & 5 & 1.0000 & 0.8180 & 8 & -3 & -0.0447 \\
\hline Standard Chartered Bank & 0.9396 & 0.8984 & 3 & 1.0000 & 0.9002 & 3 & 0 & 0.0017 \\
\hline State Bank of India & 1.0000 & 0.9065 & 1 & 1.0000 & 0.9178 & 1 & 0 & 0.0113 \\
\hline HSBC & 0.9491 & 0.9013 & 2 & 1.0000 & 0.8523 & 5 & -3 & -0.0490 \\
\hline
\end{tabular}

Correlation coefficient between efficiency in 2009 and difference in efficiency during the period $=-0.68$

\section{Conclusions and Policy Recommendations}

The study has evaluated the efficiency of Sri Lankan commercial banks for the period 2009-2012 based on the intermediation and operating approaches and using DEA with the bootstrap technique. In general the findings indicate that, irrespective of which approach is considered, a higher average efficiency level of the state-owned banks is obtained relative to domestic private banks particularly in 2011 and 2012. This could be justified as the state-owned banks were able to improve their lending by expanding their branch networks more aggressively after the ending of the armed-conflict, with the government encouraging them to expand into conflict-affected areas. This finding for Sri Lanka is against the majority of the literature on banking efficiency which provides support for the higher efficiency of private banks relative to state-owned banks in other countries (Altunbas et al., 2001; Berger, 2007; Burki \& Niazi, 2010; Demir et al., 2005; Fries \& Taci, 2005). Therefore, this study has revealed higher average efficiency in state-owned banks relative to domestic private banks during a post-conflict economic expansion period.

Several implications arise when private sector banks are relatively less efficient. First, if a private bank is not efficient, particularly in its operations, it could be forced out of the banking industry by more efficient banks, resulting in instability of the banking system. Second, from a macroeco- 
nomic policy point of view, inefficiency in domestic private banks in Sri Lanka could lead to underutilization of limited financial resources in the banking system and sub-optimal allocation of funds more generally within different sectors of the Sri Lankan economy. As the market share of domestic private banks suggests an increasing trend (Hemachandra, 2009), policy makers should take a holistic approach to ensure equal business opportunities for all banks by addressing any limitations faced by domestic private banks operating in Sri Lanka.

In general, state-owned banks and domestic private banks outperformed foreign banks during the reference period under the intermediation approach. It could not be expected that foreign banks would achieve higher efficiency particularly under the intermediation approach, since foreign bank branches might not be able to improve their lending base after the ending of the armedconflict due to their restricted coverage to only major cities in Sri Lanka. Although banks such as HSBC, the largest foreign bank in Sri Lanka, expanded their branch network in the post conflict period, the efficiency of their intermediation services are relatively low. The intermediation services provided by foreign banks, with access to considerable external funds, are also very important for a small liberalised economy like Sri Lanka to improve the availability of credit which is a pre-requisite of economic expansion. According to the literature, foreign banks could be inefficient in developing countries due to weaknesses in regulatory environments (Berger, 2007; Berger \& De Young, 2001). Therefore, existing regulations should be assessed by policy makers and necessary reforms should be introduced based those assessments to improve the participation of foreign banks in the development of Sri Lanka. However, the operational efficiency of foreign banks was high during this period, and it is obvious that they are more focused on profit maximisation than providing intermediation services. In addition, the Sri Lankan banking industry could benefit from the spill overs from advanced technology used by some foreign banks to achieve higher operational efficiency.

When comparing the changes in efficiency from 2009 to 2012 for each bank under the intermediation approach, dispersion of the efficiency scores of the sample declined during the period while recording an increase in efficiency scores for most banks. These findings reflect the convergence of efficiency of the banking sector towards relatively higher levels. This would not be considered as a salutary move if the overall efficiency level of the industry is still at a lower level. While maintaining less dispersion in efficiency of intermediation services among the banks operating in the country, policy makers should also formulate necessary strategies to improve the overall performance of banking institutions. Under the profit oriented operating approach the dispersion of efficiency did not decline within this period. Therefore differences in the operational efficiency in the banking sector could be expected to remain while the overall level of efficiency is improving. Operational inefficiency would not be good for the long run survival of banking institutions. There could be some bank-specific factors such a technology adoption, staff recruitment and external factors such as the exchange rate and interest margins which influence the operation and profitability of the banks. Therefore, bank-specific remedial measures to address operational inefficiency should be taken to minimise the inequality in efficiency levels of banking institutions.

Further, the results reveal that banks with lower efficiency in 2009 subsequently recorded higher growth in efficiency during the reference period based on both the intermediation and operation approaches. Therefore, relatively less efficient banks are in a process of catching up with other banks achieving a higher efficiency level. This catching-up was observed in Sri Lanka's postconflict economic expansion period which provided a good opportunity for banks to exploit advantages arising from high demand for credit. This trend should be maintained in the medium and long run to achieve higher overall efficiency and minimise inequality in the efficiency of banking institutions.

Overall, it can be concluded that the state-owned banks are well positioned in the post-conflict era to provide intermediation services while maintaining profitability along with limited intervention 
by regulators and the government. The higher efficiency recorded by state-owned banks relative to domestic private banks under the profit-oriented operating approach could be a reflection of minimum intervention by the government of Sri Lanka on the banking operations of state-owned banks.

\section{References}

Altunbas, Y., Evans, L., \& Molyneux, P. (2001). Bank ownership and efficiency. Journal of Money, Credit and Banking, 33, 926-954.

Andries, A. M. (2011). The determinants of bank efficiency and productivity growth in the central and eastern european banking systems. Eastern European Economics, 49(6), 38-59.

Arifat, S. N. (1972). Efficiency estimation of production Functions. International Economic Review, 13, 568-598.

Arjomandi, A., Harvie, C., \& Valadkhani, A. (2012). An empirical analysis of Iran's banking performance. Studies in Economics and Finance, 29(4), 287-300.

Arjomandi, A., Valadkhani, A., \& O’Brien, M. (2014). Analysing banks' intermediation and operational performance using the Hicks-Moorsteen TFP index: The case of Iran. Research in International Business and Finance, 30, 111-125.

Banker, R. D., Charnes, A., \& Cooper, W. W. (1984). Some models for estimating technical and scale efficiencies in data envelopment analysis. Management Science, 30, 1078-1092.

Barros, C. P., Chen, Z., Liang, Q. B., \& Peypoch, N. (2011). Technical efficiency in the Chinese banking sector. Economic Modelling, 28, 2083-2089.

Barth, J. R., Bertus, M., Hai, J., Hartaska, V., \& Phumiwasana, T. (2006). A cross-country analysis of bank performance: The role of external governance. Paper presented at the FMA annual meeting, Salt Lake City, UT, October 11-14.

Becht, M., Bolton, P., \& Roell, A. (2002). Corporate governance and control. Working Paper. European Corporate Governance Institute, Brussels.

Berger, A. N. (2007). International comparisons of banking efficiency. Financial Markets, Institutions \& Instruments, 16(3), 119-144.

Berger, A. N., \& De Young, R. (2001). The effects of geographic expansion on bank efficiency. Journal of Financial Services Research, 19(2), 163-184.

Berger, A. N., \& Mester, L. J. (2003). Explaining the dramatic changes in performance of US banks: Technological change, deregulation, and dynamic changes in competition. Journal of Financial Intermediation, 12, 57-95.

Berger, A. N., \& Humphrey, D. B. (1991). The dominance of inefficiencies over scale and product mix economies in banking. Journal of Monetary Economics, 28(1), 117-148.

Berger, A. N., Hancock, D. \& Humphrey, D. B. (1993). Bank efficiency derived from the profit function. Journal of Banking and Finance, 17, 317-347.

Bhattacharyya, A., Lovell, C. A. K., \& Sahay, P. (1997). The impact of liberalization on the productive efficiency of Indian commercial banks. European Journal of Operational Research, 98, 332-345.

Bokpin, G. A. (2013). Ownership structure, corporate governance and bank efficiency: An empirical analysis of panel data from the banking industry in Ghana. Corporate Governance, 13(3).

Bos, J. W. B., \& Kolari, J. W. (2005). Large bank efficiency in Europe and the United States: Are there economic motivations for geographic expansion in financial services? Journal of Business, 78(4), $1555-1592$. 
Burki, A. A., \& Niazi, G. S. K. (2010). Impact of financial reforms on efficiency of state-owned, private and foreign banks in Pakistan. Applied Economics, 42, 3147-3160.

Casu, B., \& Girardone, C. (2009). Testing the relationship between competition and efficiency in banking: A panel data analysis. Economics Letters, 105, 134-137.

Casu, B., \& Molyneux, P. A. (2003). Comparative study of efficiency in European banking. Applied Economics, 35(17), 1865-1876.

Central Bank of Sri Lanka (CBSL). (1998). 50th Anniversary Publication: Economic Progress of Independent Sri Lanka,CBSL, Colombo.

Central Bank of Sri Lanka (CBSL). (2010). Annual Reports, CBSL, Colombo.

Central Bank of Sri Lanka (CBSL). (2011). Annual Reports, CBSL, Colombo.

Central Bank of Sri Lanka (CBSL). (2012). Annual Reports, CBSL, Colombo.

Charnes, A., Cooper, W. W., \& Rhodes, E. (1978). Measuring the efficiency of decision making units. European Journal of Operational Research, 2, 429-444.

Das, A., \& Ghosh, T. S. (2006). Financial deregulation and efficiency: An empirical analysis of Indian banks during the post reform period. Review of Financial Economics, 15,193-221.

De Guevara, J. F., \& Maudos, J. (2002). Inequalities in the efficiency of the banking sectors of the European Union. Applied Economics Letters, 9(8), 541-544.

Demir, N., Mahmun, N., \& Babuscu, S. (2005). The technical inefficiency effect of Turkish banks after financial liberalization. The Developing Economies, 43(3), 396-411.

Drake, L., Hall, M. J. B., \& Simper, R. (2006). The impact of macroeconomic and regulatory factors on bank efficiency: A non-parametric analysis of Hong Kong's banking system. Journal of Banking \& Finance, 30, 1443-1466.

Färe, R., Grosskopf, S., \& Logan, J. (1983). The relative efficiency of Illinois electronic utilities. Resources and Energy, 5, 349-367.

Farrell, M. J. (1957). The measurement of productive efficiency. Journal of Royal Statistical Society, 120, $253-281$.

Fries, S., \& Taci, A. (2005). Cost efficiency of banks in transition: Evidence from 289 banks in 15 postcommunist countries. Journal of Banking and Finance, 29(1 Spec. issue), 55-81.

Gerschenkron, A. (1962). Economic backwardness in historical perspective. Cambridge, MA: Harvard University Press.

Grabowski, R., Rangam, N., \& Rezvanian, R. (1993). Organizational forms in banking: An empirical investigation of cost efficiency. Journal of Banking and Finance, 17, 531-538.

Grigorian, D.A., \& Manole, V. (2002). Determinants of commercial bank performance in transition: An application of data envelopment analysis. IMF Working Paper No. 02/146.

Hasan, L., \& Marton, K. (2003). Development and efficiency of the banking sector in a transitional economy: Hungarian experience. Journal of Banking \& Finance, 27, 2249-2271.

Havrylchyk, O. (2006). Efficiency of the Polish banking industry: Foreign versus domestic banks. Journal of Banking \& Finance, 30, 1975-1996.

Hemachandra, W. M. (2009). Competition and financial sector development in Sri Lanka. Sri Lanka Journal of Advanced Social Studies, 2(1), 80-121.

Isik, I., \& Hassan, M. K. (2002). Technical, scale and allocative efficiencies of Turkish banking industry. Journal of Banking and Finance, 26, 719-766.

Isshaq, Z., \& Bokpin, G. A. (2012). Expansion and efficiency in banking: Evidence from Ghana. Managerial and Decision Economics, 33, 19-28. 
Johnson, S. P., Boone, A. B., \& Friedman, E. (2000). Corporate governance in the Asian financial crisis. Journal of Financial Economies, 58, 141-186.

Kalirajan, K. P., \& Shand, R. T. (1994). Economics in disequilibrium: An approach from the frontier. India: MacMillan.

Kenjegalieva, K. A., Simper, R., \& Weyman-Jones, T. G. (2009). Efficiency of transition banks: Intercountry banking industry trends. Applied Financial Economics, 19(19), 1531-1546.

Keramidou, I., \& Mimis, A. (2011). An application of the double-bootstrap data envelopment analysis to investigate sources of efficiency in the Greek poultry sector. World's Poultry Science Journal, 67(4), $675-686$.

La Porta, R., Lopez, F., \& Shleifer, A. (2002). Government ownership of banks. Journal of Finance, 57(1), 265-301.

Lensink, R., Meesters, A., \& Naaborg, I. (2008). Bank efficiency and foreign ownership: Do good institutions matter? Journal of Banking \& Finance, 32, 834-844.

Liu, J. S., Lu, L. Y. Y., Lu, W. M., \& Lin, B. J. Y. (2013). A survey of DEA applications. Omega, 41(5), 893-902.

Mamatzakis, E., Staikouras, C., \& Koutsomanoli-Filippaki, A. (2008). Bank efficiency in the new European Union member states: Is there convergence? International Review of Financial Analysis, 17(5), 1156-1172.

Maudos, J., Pastor, J. M., Francisco, P., \& Javier, Q. (2002). Cost and profit efficiency in European banks. Journal of International Financial Markets, Institutions and Money, 12, 33-58.

Sufian, F. (2009). Determinants of bank efficiency during unstable macroeconomic environment: Empirical evidence from Malaysia. Research in International Business and Finance, 23, 54-77.

Sahoo, B. K., \&Tone, K. (2009). Decomposing capacity utilization in data envelopment analysis: An application to banks in India. European Journal of Operational Research, 195, 575-594.

Paradi, J. C., \& Zhu, H. (2013). A survey on bank branch efficiency and performance research with data envelopment analysis. Omega, 41(1), 61-79.

Ray, S. C., \& Das, A. (2010). Distribution of cost and profit efficiency: Evidence from Indian banking. European Journal of Operational Research, 201(1), 297-307.

Seelanatha, S. L. (2012). Drivers of technical efficiency of Sri Lankan commercial banks. International Journal of Applied Economics, 9(1), 41-58.

Sherman, H. D., \& Gold, F. (1985). Bank branch operating efficiency. Evaluation with data envelopment analysis. Journal of Banking and Finance, 9(2), 297-315.

Shleifer, A., \& Vishny, R. W. (1997). A survey of corporate governance. Journal of Finance, 52(2),737783.

Simar, L., \& Wilson, P. W. (1998). Sensitivity analysis of efficiency scores: How to bootstrap in nonparametric frontier models. Management Science, 44(1), 49-61.

Simar, L., \& Wilson, P. W. (2000). Bootstrapping in non-parametric frontier models. Journal of Applied Statistics, 27, 779-802.

Simar, L., \& Wilson, P. W. (2007). Estimation and inference in two-stage, semi-parametric models of production processes. Journal of Econometrics, 136(1), 31-64.

Sufian, F. (2009). Determinants of bank efficiency during unstable macroeconomic environment: Empirical evidence from Malaysia. Research in International Business and Finance, 23, 54-77.

Sufian, F. (2011). Benchmarking the efficiency of the Korean banking sector: A DEA approach. Benchmarking, 18(1), 107-127. 
Zajc, P. (2006). A comparative study of bank efficiency in Central and Eastern Europe: The role of foreign ownership. International Finance Review, 6, 117-156.
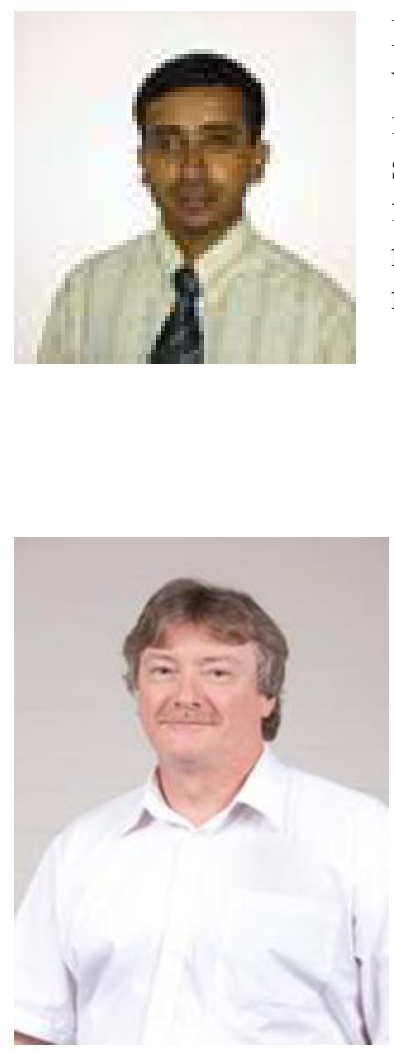

\section{Biographies}

Bolanda Thilakaweera is a PhD candidate in Faculty of Business, University of Wollongong, Australia. He received a B.Sc. Honours Degree in Statistics and an MA Degree in Financial Economics from the University of Colombo and an M.Sc. in International Economics and Finance from the University of Queensland, Australia. His research interests are mainly in the areas of banking efficiency, economic growth and econometric modeling..

Charles Harvie is an Associate Professor School of Accounting Economics and Finance, Faculty of Business, University of Wollongong, Wollongong, Australia and Director of the Centre for Small Business and Regional Research. He received his Ph.D from the University of Warwick, UK, his MA from McMaster University, Canada, and his BA from the University of Strathclyde, UK. Dr Harvie has been the sole or joint author of 6 books with publishers that include Routledge (UK) and Palgrave-Macmillan (UK). He has been the editor of a further 10 books published by Edward Elgar (UK/USA) and PalgraveMacmillan (UK). He has published 58 chapters in numerous books, 101 articles in refereed conference proceedings and 67 refereed journal articles in journals such as Energy Economics (UK), Journal of Asian Economics (USA), Economic Modelling (UK) Australasian Accounting Business and Finance Journal (Australia), Applied Economics (UK), Manchester School (UK), Journal of the Korean Economy (S. Korea), Studies in Economics and Finance (UK), Journal of Policy Modelling (Holland), Korean Economic Review (Korea), Singapore Economic Review (Singapore), Australian Economic History Review (Australia), Journal of Social Economics (USA), ASEAN Economic Bulletin (Singapore), Journal of Industrial Relations (Australia) and Resources Policy (USA).

Dr Harvie has conducted extensive research on the economies of East Asia and has written numerous books and articles on the Korean, Chinese and Vietnamese economies as well as articles on various aspects of economic development in the region. He has also written extensively on the role and contribution of small and medium enterprises (SMEs) within the region and their contribution to current and future economic development and integration in the region.

Dr Harvie has recently been involved in a number of consulting activities related to regional economic development issues in East Asia and these include the following:

1. A report for the Asian Productivity Organisation (based in Tokyo) concerned with SME Productivity Measurement (2013)

2. Small and Medium-sized Enterprises Assessment, Strategy and Road Map - an Update, Lao PDR, prepared for Asian Development Bank, (2013). 
3. Small and Medium Enterprises (SMEs) Access to Finance in Selected East Asian Economies, Economic Research Institute for ASEAN and East Asia (ERIA), Indonesia ( 2012-13).

4. Integrating Small and Medium Enterprises (SMEs) into the More Integrated East Asia, Economic Research Institute for ASEAN and East Asia (ERIA), Indonesia (2008-09).

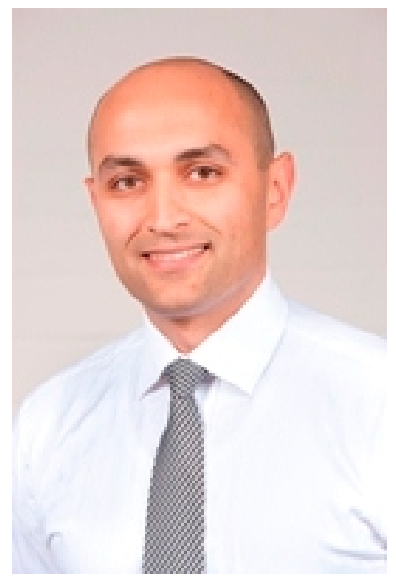

Amir Arjomandi is a Lecturer at the School of Accounting, Economics and Finance, University of Wollongong. His research interests are in Efficiency and Productivity; Environmental Economics; Applied Microeconomic Modelling; Quantitative Methods for Management. Amir has reviewed articles for several journals including Economic Modelling, Annals of Operations Research, Journal of Asian Economics, Singapore Economic Review, Applied Economics, Emerging Markets Finance and Trade, Studies in Economics and Finance, Quarterly Review of Economics and Finance, Accounting Research Journal, Economic Notes, Australasian Accounting, Business and Finance Journal, Australasian Journal of Regional Studies, Managerial Finance, and African Journal of Business Management. He is currently in the editorial board of International Journal of Economics and Finance. 